\title{
Research on the Coordinated Development of Entrepreneurship Education under the Background of the Integration of Beijing, Tianjin and Hebei
}

\author{
Li-zhen JIN ${ }^{1, a, *}$ and Xiao-li LIN² \\ ${ }^{1,2}$ College of Law and Politics, Tianjin University of Technology, Tianjin, China \\ ajinlizhen2006929@163.com
}

Keywords: Integration of Beijing, Tianjin and Hebei, Entrepreneurship education, Coordinated development.

\begin{abstract}
In the background of the integrated development of Beijing Tianjin Hebei, innovative talents to drive a crucial role for the development of the core technology industry in regional economy, colleges and universities as human resources and science and technology productivity combination, and delivery of innovative talents of high quality training is more important. Research on the development of entrepreneurship education in Tianjin University, for the coordination of the integration of the three entrepreneurship education resources, and build a better platform for exchanges and cooperation, put forward suggestions to better promote the implementation of national innovation driven development strategy.
\end{abstract}

\section{The Current Situation and Problems of Entrepreneurship Education in General Colleges and Universities in Beijing, Tianjin and Hebei}

At present, although China has made some achievements in entrepreneurship education, entrepreneurship education in our country is still in its infancy, the vast majority of colleges and universities remain in the business planning competition and employment guidance. Beijing, Tianjin and Hebei Province as one of the fastest growing areas of China, it should be in the forefront of entrepreneurship education in the country, however, the current situation of entrepreneurship education and local economic development requirements there is still a gap.

\section{The Distribution of Educational Resources in Three Provinces of Beijing, Tianjin and Hebei}

As the China's Higher Education Center, Beijing has more than and 200 universities, including 32 municipal institutions, colleges and universities in 30.9 of them as the "985 Project" focus on the construction of University, the construction of the "211 Project" of the university. A total of 44 colleges and universities in Tianjin, the "985 Project" focus on the construction of the University, the construction of the "211 Project", the University of Hebei, only about 26 colleges and universities, including the construction of the University of the "211 Project" of the 1 "". The number of colleges and universities compared with the total population, that is, the number of universities per million people, Beijing is 5.22, Tianjin is 4.18 , Hebei is 1.47 , the number of graduate training institutions in Beijing is times the number of. It can be seen that the structure of higher education in the three areas is a ladder like distribution, which objectively meets the necessary conditions of agglomeration effect, but may result in unbalanced distribution of human resources, which is not conducive to the flow of talent. Hebei province and Beijing City, Tianjin city in the differences in teachers, local financial investment in education and other aspects, there is a big 
difference, for the three places of entrepreneurship and innovation education has brought some obstacles to the development of cooperation.

\section{Weak Awareness of Entrepreneurship Education, Entrepreneurship Education Curriculum System is not Perfect}

Beijing, Tianjin and Hebei Universities are mostly carried out entrepreneurship education, but did not integrate into the whole school physical education system, the concept of education is not clear, has long been in accordance with the "employment education" model to develop talent. Most of the entrepreneurship education only in organized entrepreneurship competition, entrepreneurship guidance and report of the elite, obvious signs, is concerned with a few impressive performance, not to guide students to establish "everywhere is the venture, everyone is an Entrepreneurial consciousness.

University Entrepreneurship Education in China started late, weak foundation of discipline, not the entrepreneurship education into the subject catalog, not set up a systematic and comprehensive entrepreneurship education courses, just use their spare time to carry out entrepreneurial guidance and entrepreneurship competition guiding entrepreneurship education as the main content, a direct consequence of this approach is to make Entrepreneurship education from the professional disciplines, so that the students lose their discipline and professional advantage of the favorable rely on, is difficult to fully improve students' quality of entrepreneurship. On the other hand, entrepreneurship education in Colleges and universities has not yet formed a scientific and systematic entrepreneurship education teaching system.

\section{The Lack of Innovative, Entrepreneurial Awareness of Teachers}

Entrepreneurship education is a comprehensive discipline, is a complex subject in sociology, management and related professional knowledge and practical ability, this characteristic makes the theory and practice of entrepreneurship education is very strong need of teachers. But the team entrepreneurship teachers colleges are facing the Beijing Tianjin Hebei foundation is weak, the plight of congenitally deficient. At present, the faculty is the employment guidance department, student management department part-time teaching, most of them lack of entrepreneurial experience, but also the lack of entrepreneurship education training, entrepreneurship practice teaching is empty talk. At the same time, because entrepreneurship education. Teachers are part-time entrepreneurship education, has its own division of the Department, entrepreneurship teaching can only be a subsidiary of the work, it is difficult to put a lot of effort into practice. Lack of entrepreneurial knowledge, entrepreneurship education law is not enough to cope with trouble, the teaching effect can be imagined.

\section{Beijing, Tianjin and Collaborative Innovation and Entrepreneurship System is not Perfect in Three Places}

Since the development of Beijing, Tianjin and collaborative development strategy, the three higher educations has become the basic consensus of the linkage, carried out various forms of exchange and cooperation, and achieved some results. But the three education policy and universities are obvious with local protection thought more or less, the joint office of collaborative innovation system is not perfect, the lack of coordination of innovation platform affects the distribution of education resources sharing, to some extent hindered the Beijing Tianjin Hebei Higher Education Investment 
Cross regional cooperation. At present, the Beijing Tianjin Hebei region in the direction of personnel training of higher education on the lack of systematic guidance, facing the new situation, some colleges and universities teaching ideas and teaching goals are not clear, the lack of teaching orientation, high repeatability of the professional setting, education method is single, still in school education, classroom education is the main way. Comparison of regional economic integration of Beijing Tianjin Hebei region, higher education integration reflects the lag ideas of higher education, administrative barriers, administrative concept within the domain of higher education quite distinct from each other, leading to lack of coordination training three, closed to each other, the lack of top-level design, for higher education personnel training has not formed a unified collaborative development consensus.

\section{The Coordinated Development Counter Measures of Entrepreneurship Education for Beijing, Tianjin and Hebei Province \\ Construction of Beijing, Tianjin and Hebei Universities' Education Resources Complementary Platform}

The development of Beijing Tianjin Hebei integration of the national strategy require regional integration of higher education development, the current three of Tianjin unbalanced education resources, must carry out overall planning, scientific layout, three areas of complementary advantages, abandon the inferior original mode of cooperation, to achieve the goal of win-win cooperation. Integration of higher education resources in the region, we should give full play to the local advantages of Beijing, Tianjin and Hebei, cross administrative areas, promote the integration of higher education resources, and then with the Tokyo Tianjin Hebei Higher Education Integration process. Beijing, Tianjin and colleges and universities to promote consultation and coordination, the development of a detailed development plan, the establishment of a corresponding linkage system, the talent training and talent to attract effective links.

In recent years, Beijing University of Technology, Tianjin University of Technology, Hebei University of Technology, three schools jointly set up the Beijing Tianjin Hebei collaborative innovation alliance". Beijing University of architecture, Tianjin University of urban construction, Hebei Institute of Architecture and Civil Engineering, also co founded the Beijing, Tianjin and architectural collaborative innovation alliance, will enhance the sharing of teaching resources as one of its important objectives. 260 colleges and universities with the Beijing Tianjin Hebei region, a considerable part of the school in the country has the absolute advantage of industry and professional field, the realization of various professional disciplines complementary educational resources, will greatly improve the quality and efficiency of innovation and entrepreneurial talents. The advantages of the scientific research achievements of the universities, the integration of local resources to cultivate professional talents and the degree of the industry well-known laboratory information is the advantage of the platform can be used. The linkage between the school teaching resources can flow to the students through teaching school, also available through online courses to share, or explore other more effective interactive mode, thus a good platform for entrepreneurship education for the college students to realize the sharing of teaching resources. 


\section{Set up the Cross and Integration of Entrepreneurship Courses in Different Disciplines of Colleges and Universities}

The establishment of entrepreneurship and innovation courses should not only meet the basic requirements of their major, but also broaden their cognitive areas, so that students can be "special" and "pass", in order to effectively play the role of innovation and entrepreneurship courses. In addition to professional management knowledge, students should do arts and. Today, entrepreneurs are becoming an important factor of production, so that students of the humanities and natural science courses are covered, to enhance their basic quality. Therefore, it is necessary to sort out and design teaching content in order to transform knowledge into productivity. Secondly, knowledge and ability, knowledge is important, but can play a role in the practice of knowledge is useful knowledge and living knowledge. Therefore, the curriculum should include a large number of training courses to inspire students' innovative thinking and cultivate students' ability of innovation and entrepreneurship. The specific courses can be divided into two categories: professional learning and social training. Two levels of college and undergraduate, to business management specialty for example: (1) college is divided into compulsory courses and elective courses, compulsory courses in addition to regular courses, accounting, marketing, negotiation and other aspects of the curriculum is provided; elective setting more innovation and entrepreneurship related courses, such as "International Entrepreneurial Finance" the "social enterprise" effective leadership "in the social sector" entrepreneurial spirit "from the perspective of entrepreneurial enterprises globalization evolution", etc.. (2) undergraduate students are divided into compulsory courses and elective courses, compulsory courses in addition to compulsory courses of college, to highlight the case curriculum, especially the research type courses, such as "entrepreneurial management" course, divided into how to become entrepreneurial talent, entrepreneurial base, growth enterprise management, how to realize the profit and a number of parts, each part is served for discussion with a large number of cases, and ask the students to practice the project corresponding to the group as a unit, through competition, profit group satisfaction to determine its credit; elective courses and elective courses with specialist. (3)Social training class.Such courses for those who are willing to carry out innovative entrepreneurship. These courses use the Open University and the cooperation of enterprises and units, the preparation of the best teachers to organize seminars, forums, salons or short-term workshops and other forms of training. The scope of work to the environment from the public welfare of education, community development, and then to the various enterprises operating environment of different areas of business management, occupation career, personal development and other aspects of the problem.

At the same time, the harmonious development of entrepreneurship education should also choose a flexible teaching method, since it is innovation and entrepreneurship education; it should not be defined from the perspective of students. In the past, the paper examination is often a variety of concepts, innovation and entrepreneurship education to encourage students to express their own ideas, through thinking, put forward their own understanding. The exam can open book, case analysis or writing papers, or even a quantitative index practice project.Reforming the classroom. In traditional education, the students are sitting together to listen to the radio, watch TV, but now is the network teaching, the teaching process of "What I say goes." in the form of many. Innovation and entrepreneurship education, must change the "What I say goes." teaching methods, can invite experts and scholars, especially have a certain practical ability in various talents to teach, to allow the thought of 
"collision", actively discuss the problem, thinking and methods of management of various exercises. Encourage group learning. Open University has been encouraging group learning, but there is a big gap between the real team. In the course of innovation and entrepreneurship, to organize the students to form a real team, design a lot of plans for each team to prepare separately reading materials, case discussions, competition. Practice teaching. Innovation and entrepreneurship education is different from general education, the theory of the first pass, and then participate in practice. In the base construction of various colleges and universities, students can spare time, while the actual participation, while continuing to theoretical research, to encourage students to learn the experience of your own work, the new problems encountered in the work in class discussion, excellent platform to build professional person to grow.

\section{To Alleviate the Imbalance in the Development of Higher Education in the Field of Employment Market Demand}

Entrepreneurial innovation education is the accumulation of human resources, in essence is to meet the needs of the job market, so the layout of entrepreneurship education should be coordinated with the employment status of layout, development and appropriate leading in the job market. Taking employment as the modern system of entrepreneurship education oriented construction is an important content of deepening the comprehensive reform of education, the state should be based on the three of the population of employment and employment planning layout, guide three adjusted for entrepreneurship education resources layout, jointly build collaborative development of innovation and entrepreneurship education system across the administrative division, covering three.

Beijing, Tianjin and Hebei province in terms of higher education resources, the level of higher education, the quality of personnel training and other aspects of the gap is objective and realistic. It is not right to ignore the difference, to emphasize the balance and to emphasize the gap, so as to maintain the original training mode. The use of the existing network technology and knowledge platform, to build a higher education network system, the construction of Beijing, Tianjin and Higher Education Alliance, are feasible in the short term. Through online education technology, realize the sharing of the educational content, construct the mutual recognition of personnel evaluation system, try to carry out the talent training of higher education is no difference in the domain, can ease the allocation of educational resources in a certain extent uneven, promote coordinated development of regional education.

\section{Relying on the Scientific and Technological Resources of Beijing, Tianjin and the Advantages of Experts to Inject Vitality into Entrepreneurship Education in Colleges and Universities}

Science and technology is the internal driving force of economic development and the important support for the long-term development of modern enterprises. Experts not only grasp the relevant field of high-end technology, but also led to the implementation of the project, the policy and the implementation of the flow of funds. Beijing, Tianjin and Hebei region is one of the most scientific and technological vitality of the regional economic circle, in promoting the transformation of scientific and technological achievements and industrial restructuring on the concentration of considerable expert advantage. Beijing Tianjin Hebei university should make full use of the three technology and expert resources, to face the three industrial, government technical problems and demand, carry out with the resources and rely on entrepreneurship education to solve the practical problems of development oriented. 
The Beijing and Tianjin have different industrial advantages, location of each functional area are not the same, the science and technology achievements and entrepreneurial talent training "for people", not only to avoid the regional homogeneity competition, guide the adjustment of industrial structure, but also conducive to scientific research more fully enjoy the preferential policies and industrial cluster advantage in transformation. At the same time, make full use of expert resources can not only realize the re layout of high-tech industry in Beijing Tianjin Hebei, also can activate local existing resources endowment and dividend policy, and make innovative entrepreneurial talent in less developed area attracted into, stay".

\section{Coordinating the Social Resources of Beijing, Tianjin and Establishing the Mechanism of Integration of Production and Education}

To improve the business environment and education resources, realize the coordinated development of Beijing Tianjin Hebei three undergraduate entrepreneurship education in Colleges and universities, in addition to the use of talents and education resources, colleges and universities should also be coordinated through their own social resources to entrepreneurship education resources for the Beijing Tianjin Hebei integration support.

At present, all the major colleges and universities the entrepreneurial quality training and innovation related courses in entrepreneurship education, cultivate innovative talents but need not only professional ability and innovative thinking, but also need to accept the training of finance, management, psychology and other aspects. The three universities should coordinate social resources and resources of local enterprises, the establishment of a unified information sharing platform, to provide timely, accurate and equal entrepreneurship policies, financing, business incubator information for entrepreneurs; Beijing Tianjin Hebei University Alumni Resources activation, docking government policy, attention to industry and the people's livelihood, environmental issues, provide recommendations for governance smart government and enterprise cooperation; joint training of personnel development, the promotion of enterprise innovation ability, provide technical support for regional economic development. At the same time, three of Tianjin University according to their own characteristics and advantages, focus on the development of a course or project, take more turns, school, school enterprise Jo form training, not only can reduce the cost, but also can expand students horizons, the entrepreneurship education quality and efficiency.

\section{Acknowledgement}

This research was financially supported by the Tianjin philosophy and social science research program (Project No.: TJJX16-005).

\section{Reference}

[1] Luo, Zeyi. The necessity and realization: the logic of the overall planning of innovation and entrepreneurship education resources [M]. Hunan University of Science and Technology press, 2016

[2] Wu Jiahui. Study on the path of entrepreneurship education in Applied Undergraduate Universities [M]. Hebei Education Press, 2016.(in Chinese) 
[3] An Bo. Analysis of College Students' innovation and Entrepreneurship Education under the background of the coordinated development of Beijing, Tianjin and Hebei [M].modern economic information publishing house, 2016.(in Chinese)

[4] XueHao. Reflection on the misunderstanding and Countermeasures of entrepreneurship education in Colleges and universities [J]. Journal of Huazhong University of Science and Technology, 2016.(in Chinese)

[5] Wu Yan. Higher education dream -- China on the new development of regional higher education [M]. Beijing: Higher Education Press, 2013.(in Chinese)

[6] Zhuang Shiying, Zhou Junqin, Cui Yanming. Analysis of the status quo of the Beijing Tianjin Hebei regional higher education history from [J].2009 (11)..(in Chinese) 